\title{
Model-Model Penyelesaian Sengketa Ekonomi Syariah di Indonesia
}

\author{
${ }^{1}$ Neni Hardiati, ${ }^{2}$ Sindi Widiana, ${ }^{3}$ Seproni Hidayat \\ 1-2 UIN Sunan Gunung Djati \\ ${ }^{3}$ STAI Yamisa
}

Article history

Received: 02-Mei-2021

Revised: 12-Juni-2021

Accepted: 28-Juli-2021

*Corresponding Author:

Neni Hardiati

Sindi Widiana

Seproni Hidayat

1-2 UIN Sunan Gunung Djati

${ }^{3}$ STAI Yamisa

Email:

nenihardiati@gmail.com

sindiwidiana69@gmail.com

shidayat@yamisa.ac.id

\begin{abstract}
Abstrak: Pertumbuhan ekonomi sangat sejalan dengan era saat ini, dan sulit bagi masyarakat untuk memecahkan masalah antara ekonomi syariah Indonesia untuk memecahkan masalah ekonomi. Pada penelitian menjelaskan model-model dalam penyelesain pada sengketa ekonomi syariah. Jenis penelitian yang digunakan adalah penelitian kepustakaan, dengan menggunakan dua metode, yaitu metode normatif dan metode yuridis. Dan hasil penelitian ini menemukan bahwa (1) ketika menyelesaikan sengketa berdasarkan tradisi Islam klasik, yaitu melalui $\mathrm{Al}$ Sulh (perdamaian), Tahkim (arbitrase) dan Wilayat al Qadha (kekuasaan kehakiman) (2) penyelesaian ekonomi Syariah dapat dicapai melalui Penyelesaian sengketa berdasarkan tradisi hukum aktif dengan cara-cara berikut: penyelesaian sengketa damai dan alternatif (ADR) dan arbitrase (Tahkim).
\end{abstract}

Kata Kunci : Model-model, Penyelesaian Sengketa, Ekonomi Syariah

\section{PENDAHULUAN}

Perkembangan ekonomi syariah diberbagai sektor terutama sektor regulasi tidak bisa terbantahkan, sebab seiring dengan perkembangan ekonomi syariah membutuhkan pondasi yang kokoh, oleh karenanya dibutuhkan pemahaman ekonomi syariah secara komprehensif. Di Indonesia pada tahun 2016 lahirnya Peraturan Mahkamah Agung Nomor 14 Tahun 2016 tentang Tata Cara Penyelesiaan Sengketa Ekonomi Syariah tentunya memiliki prospek kedepan dalam menyelesaikan sengketa ekonomi syariah (Ilyas, 2018).

Pertumbuhan ekonomi syariah yang semakin pesat dan kompleks, menghasilkan produk ekonomi syariah yang beragam, meningkatnya kerjasama ekonomi, tentu berimbas terhadap penyebab semakin rentannya sebab konflik atau sengketa ekonomi syariah. Hal ini sehingga akan terjadinya sengketa ekonomi syariah, diantaranya wanprestasi, perbuatan melawan hukum, kerugian salah satu pihak, adanya pihak yang tidak puas atas tanggapan yang menyebabkan kerugian dan penyebab lainnya dan keadaan memaksa. Tentu saja harapan besar bahwa ekonomi syariah berjalan sesuai dengan prinsip-prinsip syariah, namun tidak menutup kemungkinan akan terjadi implikasi yang berbeda dengan yang diharapkan dan untuk mengatasinya perlu ada aturan yang jelas dan pasti agar jalan penyelesaian sengketa mampu memberikan kepastian hukum bagi para pihak (Rinanda, 2018).

Penyelesaian sengketa ekonomi syariah telah diatur setidaknya ada dua pilihan penyelesaian sengketa, pertama, penyelesian sengketa ekonomi syariah jalur litigasi yakni penyelesaian sengketa yang diselesaikan melalui lembaga pengadilan dengan berbagai hukum acaranya. Kedua penyelesian sengketa ekonomi syariah jalur nonlitigasi yakni penyelesaian sengketa yang penyelesaiannya diselesaikan di luar pengadilan sebagai alternatif penyelesaian sengketa meliputi APS (alternative penyelesaian sengketa) atau diistilahkan ADR (alternative dispute resolution), Arbitrase, dan lembaga konsumen. Salah satu bentuk APS sebagai penyelesaian sengketa musyawarah akan dijelaskan secara 
komprehensif tentang musyawarah dari aspek hukum Islam (Makarim, 2019). Sehingga pada penelitian ini bermaksud ingin mengetahui model- model penyelesaian sengketa ekonomi Syariah yang ada di Indonesia.

\section{METODE}

Penelitian ini menggunakan pendekatan yuridis normatif yang didasarkan pada bahan hukum utama dengan mempelajari teori, konsep, dan prinsip hukum peraturan perundang-undangan yang berkaitan dengan penelitian ini. Jenis penelitian yang digunakan adalah kualitatif yaitu penelitian yang bersifat deskriptif dan cenderung menggunakan analisis. Sedangkan metode yang digunakan adalah metode penelitian analisis deskriptif, namun merupakan metode mendeskripsikan atau meringkas objek penelitian melalui data dan sampel yang dikumpulkan sebagaimana adanya. Pengumpulan data penulis menggunakan studi pustaka dari artikel dan karya ilmiah (seperti buku, jurnal, dan artikel ilmiah lainnya) yang mengandung pokok-pokok yang dapat digunakan dalam menelaah penyelesaian ekonomi syariah di Indonesia (Sugiyono, 2011).

\section{PEMBAHASAN}

\section{Landasan Teori}

\section{A.Penyelesaian Ekonomi Syariah di Indonesia}

Ekonomi syariah atau disebut juga sebagai ekonomi Islam, yaitu ekonomi berdasarkan prinsip-prinsip syari'ah. Kemudian yang dimaksud dengan ekonomi syari'ah adalah perbuatan atau kegiatan usaha yang dilaksanakan oleh perorangan, badan usaha yang berbadan hukum atau tidak berbadan hukum dalam rangka memenuhi kebutuhan yang bersifat komersial dan tidak komersial menurut prinsip syariah (Rinanda, 2018). Meliputi bank syari'ah, lembaga keuangan mikro syari'ah, asuransi syari'ah, reasuransi syari'ah, reksadana syari'ah, obligasi syari'ah dan surat berharga berjangka menengah syari'ah, dan sekuritas syari'ah, pembiayaan syari'ah, pergadaian syari'ah, dana pensiun lembaga keuangan syari'ah dan bisnis syari'ah.

Berdasarkan Pasal 49 huruf (i) UU No.3 Tahun 2006 yang pasal dan isinya tidak diubah dalam UU No.50 Tahun 2009 tentang Perubahan Kedua UU No. 7 Tahun 1989 tentang Peradilan Agama, bahwa Peradilan Agama bertugas dan berwenang memeriksa, mengadili dan menyelesaikan perkara di tingkat pertama antara orang-orang yang beragama Islam dalam bidang ekonomi syari'ah yang meliputi: (Makarim, 2019)

1. Bank syari'ah,

2. Lembaga keuangan mikro syari'ah,

3. Asuransi syari'ah,

4. Reasuransi syari'ah,

5. Reksadana syari'ah,

6. Obligasi syari'ah dan surat berharga berjangka menengah syari'ah,

7. Sekuritas syari'ah,

8. Pembiayaan syari'ah,

9. Pegadaian syari'ah,

10. Dana pensiun lembaga keuangan syari'ah, serta

11. Bisnis syari'ah.

Sehubungan dengan jenis dan macamnya mengenai ekonomi syari'ah yang disebut dalam Penjelasan Pasal 49 UU No. 3 Tahun 2006 huruf (i) di atas, hanya menyebutkan 11 jenis. Sebaiknya, harus dilihat terlebih dahulu mengenai rumusan awalnya yang menyebutkan, bahwa ekonomi syari'ah adalah perbuatan atau kegiatan usaha yang dilaksanakan menurut prinsip syari'ah, kata antara lain yang menunjukkan bahwa 11 jenis yang disebutkan bukan dalam arti limitative, namun hanya sebagai contoh. Di samping itu, 
mungkin saja ada bentuk-bentuk lain dari ekonomi syari'ah yang tidak dapat atau belum dapat disebutkan ketika merumuskan pengertian ekonomi syari'ah (Asrizal, 2018).

Subjek hukum pelaku ekonomi syari'ah menurut penjelasan pasal tersebut di atas antara lain disebutkan bahwa yang dimaksud dengan orang-orang yang beragama Islam adalah termasuk orang atau badan hukum yang dengan sendirinya menundukkan diri dengan suka rela kepada hukum Islam tentang hal-hal yang menjadi kewenangan Pengadilan Agama sesuai pada ketentuan pasal ini (Rahmi, 2015).

Berdasarkan penjelasan Pasal 49 UU. No. 3 Tahun 2006 tersebut, maka seluruh nasabah lembaga keuangan dan lembaga pembiayaan syari'ah dan atau bank-bank konvensional yang membuka sektor usaha syari'ah maka dengan sendirinya terikat dengan ketentuan ekonomi syari'ah, baik dalam hal pelaksanaan akadnya maupun dalam hal penyelesaian perselisihannya (Mukarromah, 2019).

\section{B. Alternatif Penyelesaian Sengketa Ekonomi Syariah}

Altenatif Penyelesaian Sengketa pada terminologi Islam dikenal dengan ashshulhu, yang berarti memutus pertengkaran atau perselisihan. Dalam pengertian syari'at ash-shulhu adalah suatu jenis akad (perjanjian) untuk mengakhiri perlawanan (sengketa) antara 2 (dua) orang yang bersengketa. Alternatif penyelesaian sengketa hanya diatur dalam satu pasal, yakni Pasal 6 Undang- Undang No. 30 Tahun 1999 tentang Arbitrase dan Alternatif Penyelesaian sengketa yang menjelaskan tentang mekanisme penyelesaian sengketa. Sengketa atau beda pendapat dalam bidang perdata Islam dapat diselesaikan oleh para pihak melaui Alternative Penyelesaian Sengketa yang didasarkan pada iktikad baik dengan mengesampingkan penyelesaian secara litigasi (Jamin, 1995).

Apabila sengketa tersebut tidak dapat diselesaikan, maka atas kesepakatan tertulis para pihak, sengketa atau beda pendapat diselesaikan melalui bantuan seseorang atau lebih penasehat ahli maupun melalui seorang mediator. Apabila para pihak tersebut dalam waktu paling lambat 14 (empat belas) hari dengan bantuan seorang atau lebih penasehat ahli maupun melalui seorang mediator tidak berhasil juga mencapai kata sepakat, atau mediator tidak berhasil mempertemukan kedua belah pihak, maka para pihak dapat menghubungi lembaga Alternatif Penyelesaian Sengketa untuk menunjuk seorang mediator. Setelah penunjukan mediator oleh lembaga Alternatif Penyelesaian Sengketa, dalam waktu paling lama 7 (tujuh) hari usaha (Yulianti, 2007) dengan memegang teguh kerahasiaan, dalam waktu paling lama 30 (tiga puluh) hari harus tercapai kesepakatan dalam bentuk tertulis yang ditandatangani oleh kedua belah pihak yang terkait.

Kesepakatan penyelesaian sengketa atau beda pendapat secara tertulis adalah final dan mengikat para pihak untuk dilaksanakan dengan iktikad baik serta wajib didaftarkan di Pengadilan dalam waktu paling lama 30 (tiga puluh) hari sejak penandatanganan. Kesepakatan penyelesaian sengketa atau beda pendapat tersebut wajib selesai dilaksanakan dalam waktu paling lama 30 (tiga puluh) hari sejak

penandatanganan. Tidak seperti arbiter atau hakim, seorang mediator tidak membuat keputusan mengenai sengketa yang terjadi tetapi hanya membantu para pihak untuk mencapai tujuan mereka dan menemukan pemecahan masalah dengan hasil win-win solution (Suadi, 2017). Tidak ada pihak yang kalah atau yang menang, semua sengketa diselesaikan dengan cara kekeluargaan, sehingga hasil keputusan mediasi tentunya merupakan konsensus kedua belah pihak. Pemerintah telah mengakomodasi kebutuhan terhadap mediasi dengan mengeluarkan Peraturan Mahkamah Agung (PERMA) No. 02 Tahun 2003 tentang Prosedur Mediasi di Pengadilan. 


\section{Model-model jenis Penyelesaian Sengketa Ekonomi Syariah 1.Penyelesaian Sengketa Ekonomi syariah berdasarkan tradisi Islam Klasik.}

\section{a)Perdamaian (Sulhu)}

Langkah pertama yang perlu diupayakan ketika hendak menyelesaikan perselisihan, ialah melalui cara damai. Untuk mencapai hakekat perdamaian, prinsip utama yang perlu dikedepankan adalah kesadaran para pihak untuk kembali kepada Allah (Al-Qur'an) dan Rosul-Nya (Al-Sunnah) dalam menyelesaikan segala persoalan. Upaya damai tersebut biasanya ditempuh melalui musyawarah (syuura) untuk mencapai mufakat di antara para pihak yang berselisih. Dengan musyawarah yang mengedepankan prinsip-prinsip syari'at, diharapkan apa yang menjadi persoalan para pihak dapat diselesaikan. (Jamin, 1995)

Dalam Islam sulh merupakan salah satu metode penyelesaian sengketa yang sangat dianjurkan untuk digunakan dalam menyelesaikan sengketa. Sulh dapat diartikan sebagai penyelesaian sengketa secara damai yang meliputi berbagai cara penyelesaian seperti perundingan, mediasi/konsiliasi, dan kompromi tindakan (negosiasi, mediasi/konsiliasi dan kompromi tindakan ). Kata sulh berasal dari bahasa Arab yang berarti mendamaikan (mendamaikan ) dan berdamai dengan lawan '( berdamai dengan yang berselisih ).

Sulh berasal dari kata kerja saluha atau salaha yang dalam praktik dan menurut hukum Islam berarti 'menjadi baik, benar' dan mengungkapkan gagasan perdamaian dan rekonsiliasi Sulh secara harfiah berarti ' mengakhiri perselisihan ' atau ' memutuskan perselisihan' baik secara langsung maupun dengan bantuan pihak ketiga yang netral . Menurut Ibnu Qudamah, sulh adalah negosiasi antara dua pihak yang bersengketa yang dapat membawa kepada perdamaian. Menurut Mejelle, Pasal 1531, mendefinisikan sulh sebagai akad yang menghilangkan perselisihan dengan persetujuan dan menjadi akad yang disepakati dengan penawaran dan penerimaan . Definisi di atas menunjukkan bahwa tujuan sulh adalah untuk mengakhiri konflik dan permusuhan antara pihak-pihak yang bersengketa secara damai sehingga mereka dapat mempertahankan hubungan. Sulh adalah penyelesaian berdasarkan perdamaian yang dirundingkan oleh para pihak yang bersengketa, baik sendiri maupun dengan bantuan pihak ketiga berdasarkan persetujuan para pihak yang bersengketa. Sulh adalah suatu bentuk akad dan setelah disepakati oleh para pihak menjadi mengikat secara moral. Untuk mengikat perdamaian secara hukum dapat dilakukan secara tertulis.

Di atas dijelaskan betapa pentingnya peran $\mathrm{s}$ ulh dan penyelesaian sengketa sehingga sangat dianjurkan untuk digunakan dalam Islam. Ada beberapa ayat Al- Qur'an dan hadits Nabi Muhammad SAW yang menjelaskan tentang pentingnya fungsi sulh. Diantaranya adalah sebagai berikut:

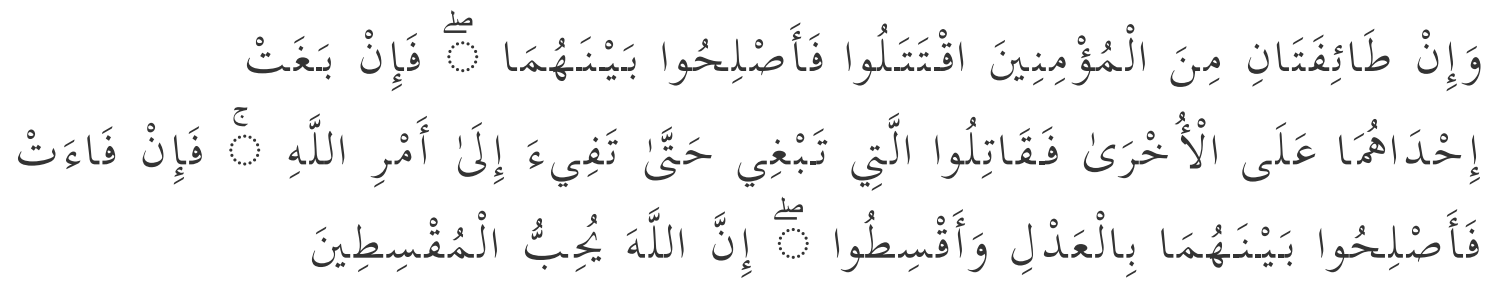

"Dan kalau ada dua golongan dari mereka yang beriman itu berperang hendaklah kamu damaikan antara keduanya! Tapi kalau yang satu melanggar perjanjian terhadap yang lain, hendaklah yang melanggar perjanjian itu kamu perangi sampai surut kembali pada perintah Allah. Kalau dia telah surut, damaikanlah antara keduanya menurut keadilan, dan hendaklah kamu berlaku adil; sesungguhnya Allah mencintai orang-orang yang berlaku adil.” (QS. Al-Hujuraat , 49: 9) 
Ayat di atas dengan jelas mendesak para pihak yang bersengketa untuk menyelesaikan perselisihan mereka secara damai (cara damai) Nabi SAW juga menganjurkan penyelesaian perselisihan secara damai dengan mengatakan: "Konsiliasi antara Muslim diperbolehkan, kecuali perdamaian yang membuat segala sesuatu haram. dan halal menjadi haram." Sejalan dengan hadits tersebut, juga terdapat risalah terkenal yang ditulis oleh Umar bin Khattab, Khalifah Islam kedua, kepada Abu Musa Al-Asy'ari, ketika diangkat sebagai hakim (qadi). Surat tersebut berisi berbagai perintah terkait penyelenggaraan peradilan. Salah satu perintah ini terkait dengan sulh yang berbunyi sebagai berikut: "Semua jenis kompromi dan perdamaian di antara umat Islam diperbolehkan, kecuali melarang segala sesuatu yang halal dan yang halal menjadi haram."

Berdasarkan hadits Nabi dan surat Umar di atas, penting untuk dicatat bahwa penggunaan konsiliasi dan kompromi untuk menyelesaikan perselisihan sangat dianjurkan. Dalam hukum Islam, mediasi dan konsiliasi dilakukan secara informal dan tidak diatur oleh aturan formal, seperti halnya lembaga mediasi saat ini yang secara kelembagaan cenderung terikat oleh berbagai aturan dan mekanisme formal. Oleh karena itu, mekanisme informal di sulh berguna dalam membantu penyelesaian sengketa.

Negosiasi bilateral dapat mengarah pada penyelesaian, jika para pihak menemukan solusi yang disepakati bersama. Jika tidak ada solusi yang disepakati bersama, maka pihak ketiga (mediator) dapat dilibatkan untuk membantu mereka menemukan solusi yang diinginkan. Jika perselisihan telah dibawa ke pengadilan, maka tindakan kompromi dapat digunakan untuk menyelesaikan perselisihan secara rasional dan saling menguntungkan. Jika sengketa tidak dapat dikompromikan, maka proses pengadilan secara otomatis akan berjalan dengan sendirinya.

Mengingat pentingnya sulhu, Pengadilan Syariah di Malaysia resmi menggunakannya pada tahun 2001. Sejak awal, hampir $70 \%$ kasus telah diselesaikan dan ini sangat membantu mengurangi tumpukan kasus. Demikian pula pada tahun 2003 Mahkamah Agung di Indonesia juga memperkenalkan mediasi sebagai bagian integral dari proses peradilan dengan diterbitkannya Peraturan Mahkamah Agung Nomor 2 Tahun 2003 yang kemudian direvisi dengan Peraturan Mahkamah Agung Nomor 1 Tahun 2008. Peraturan Mahkamah Agung ini kemudian direvisi dengan Peraturan Mahkamah Agung Republik Indonesia No. 1 Tahun 2016 tentang Tata Cara Mediasi di Pengadilan. Aturanaturan ini secara eksplisit mengatur bahwa mediasi adalah bagian dari proses litigasi dan tidak dapat dipisahkan darinya.

Berdasarkan penjelasan di atas, dapat dipahami bahwa sulh merupakan tambang emas yang harus dimanfaatkan dan digali sebagai langkah awal penyelesaian sengketa. Sulh dapat digunakan dalam menyelesaikan sengketa bisnis syariah melalui tiga tahap yang dimulai dengan negosiasi, mediasi dan kemudian kompromi dengan tindakan.Melalui mekanisme ini diharapkan sengketa bisnis syariah dapat diselesaikan dengan cepat, murah dan damai (Nurhayati, 2019).

\section{b)Arbitrase Syari'ah (Tahkim)}

Untuk menyelesaikan perkara atau perselisihan secara damai dalam hal keperdataan, selain dapat dicapai melalui inisiatif sendiri dari para pihak, juga dapat dicapai melalui keterlibatan pihak ketiga sebagai wasit (mediator). Upaya ini biasanya akan ditempuh apabila para pihak yang berperkara itu sendiri ternyata tidak mampu mencapai kesepakatan damai.

Institusi formal yang khusus dibentuk untuk menangani perselisihan/ sengketa disebut arbitrase, yaitu cara penyelesaian sengketa perdata di luar peradilan umum yang didasarkan pada perjanjian arbitrase yang dibuat secara tertulis oleh para pihak yang bersengketa (Yulianti, 2007). 


\section{c)Lembaga Peradilan Syari'ah (Qadha)}

Dengan disahkannya UU No. 3 Th. 2006 tentang perubahan UU No. 7 Th. 1989 tentang Peradilan Agama telah membawa perubahan besar dalam eksistensi lembaga Peradilan Agama saat ini. Salah satu perubahan mendasar adalah penambahan wewenang lembaga Peradilan Agama antara lain di bidang perkawinan, waris, wasiat, hibah, wakaf, zakat, infaq, shadaqah, dan ekonomi syari'ah (pasal49). Dengan adanya kewenangan ini maka perkara yang timbul terkait dengan penyelesaian sengketa syari'ah selain dapat diselesaikan melalui caradamai (sulhu) dan arbitrase syari'ah (tahkim), juga dapat diselesaikan melalui lembaga peradilan (qadha)

\section{Penyelesaian Sengketa Ekonomi Syariah Berdasarkan Tradisi Hukum Positif Indonesia}

\section{a. Perdamaian dan Alternatif Penyelesaian Sengketa (ADR)}

Menurut Wahbah Az Zuhaili, konsep sulh (perdamaian) yang dijabarkan dalam berbagai kitab, merupakan salah satu ajaran utama hukum Islam untuk menyelesaikan perselisihan di bidang muamalah, yang sudah menjadi syarat bagi kehidupan masyarakat mana pun. Sebab perdamaian hakikatnya bukan hanya sistem yang positif, tetapi lebih diwujudkan dalam bentuk fitrah manusia. Seluruh umat manusia ingin nyaman dalam segala aspek kehidupan tanpa diganggu, tidak ingin bermusuhan, dan berharap semua aspek kehidupan damai.

Dengan demikian institusi perdamaian adalah bagian dari kehidupan manusia. Pemikiran kebutuhan akan lembaga sulh (perdamaian) pada zaman modern ini tentunya bukanlah suatu wacana dan cita-cita yang masih utopis, melainkan sudah masuk ke wilayah praktis. Hal ini dapat dilihat dengan marak dan populernya Alternative Dispute Resolution (ADR). Untuk kontek Indonesia, perdamaian telah didukung keberadaannya dalam hukum positif yakni Undang-Undang Nomor 30 Tahun 1999 Tentang Arbitrase dan Alternatif Penyelesaian Sengketa. Dengan adanya pengaturan secara positif mengenai perdamaian, maka segala hal yang berkaitan dengan perdamaian baik yang masih dalam bentuk upaya, proses teknis pelaksanaan hingga pelaksanaan putusan dengan sendirinya telah sepenuhnya didukung oleh negara.

Menurut Suyud Margono kecenderungan memilih Alternatif Dispute Resolution (ADR) oleh masyarakat dewasa ini didasarkan atas pertimbangan pertama : kurang percaya pada sistem pengadilan dan pada saat yang sama sudah dipahaminya keuntungan mempergunakan sistem arbitrase dibanding dengan Pengadilan, sehingga masyarakat pelaku bisnis lebih suka mencari alternatif lain dalam upaya menyelesaikan berbagai sengketa bisnisnya yakni dengan jalan Arbitrase, kedua: kepercayaan masyarakat terhadap lembaga arbitrase khususnya BANI mulai menurun yang disebabkan banyaknya klausulklausul arbitrase yang tidak berdiri sendiri sendiri, melainkan mengikuti dengan klausul kemungkinan pengajuan sengketa ke Pengadilan jika putusan arbitrasenya tidak berhasil diselesaikan. Sengketa di luar Pengadilan, yakni melalui konsultasi, mediasi, negosiasi, konsiliasi dan penilaian ahli. Undang-Undang ini tidak seluruhnya memberikan pengertian atau batasanbatasan secara rinci dan jelas.

Berikut penjelasan singkat mengenai bentuk ADR sebagai berikut: a. Consultation Black.s Law Dictionary memberikan pengertian ini.Konsultasi adalah sejenis kegiatan konsultasi atau negosiasi, seperti proses klien dan penasihat hukumnya. C. Mediasi Mediasi adalah penyesuaian pendapat dan penyelesaian sengketa dalam suasana bersahabat dan tidak bermusuhan di ruang sidang sebelum sidang dimulai, dengan tujuan untuk menghindari prosedur hukum. d) Pendapat atau penilaian ahli (Muhammad Ibn Farhum: 1031:19) Bentuk lain dari ADR yang diperkenalkan oleh UU No. 30 Tahun 1990 adalah 
pendapat ahli (evaluasi).

Dalam rumusan pasal 52 Undang-Undang ini dinyatakan bahwa para pihak dalam suatu perjanjian berhak untuk memohon pendapat yang mengikat dari lembaga arbitrase atas hubungan hukum tertentu dari suatu perjanjian. 2. Arbitrase (Tahkim) Biasanya dalam kontrak bisnis sudah disepakati dalam kontrak yang dibuatnya untuk menyelesaikan sengketa yang terjadi dikemudian hari di antara mereka. Usaha penyelesaian sengketa dapat diserahkan kepada forum-forum tertentu sesuai dengan kesepakatan.

Di Indonesia terdapat beberapa lembaga arbitrase untuk menyelesaikan berbagai sengketa bisnis yang terjadi dalam lalu lintas perdagangan, antara lain BAMUI (Badan Arbitrase Muamalat Indonesia) yang khusus menangani masalah persengketaan dalam bisnis Islam, BASYARNAS (Badan Arbitrase Syari.ah Nasional) yang menangani masalah-masalah yang terjadi dalam pelaksanaan Bank Syari.ah, dan BANI (Badan Arbitrase Nasional Indonesia) yang khusus menyelesaikan sengketa bisnis non Islam.

\section{1)Badan Arbitrase Nasional Indonesia (BANI)}

Sebagian besar di negara-negara barat telah memiliki lembaga arbitrase dalam menyelesaikan berbagai sengketa ekonomi yang timbul akibat wanprestasi terhadap kontrak-kontrak yang dilaksanakannya. Dalam kaitan ini, Indonesia yang merupakan bagian dari masyarakat dunia juga telah memiliki lembaga arbitrase dengan nama Badan Arbitrase Nasional Indonesia yang disingkat dengan BANI. Adapun tujuan didirikannya Badan Arbitrase Nasional Indonesia (BANI) adalah memberikan penyelesaian yang adil dan cepat dalam sengketa-sengketa perdata yang timbul dan berkaitan dengan perdagangan dan keuangan, baik yang bersifat nasional maupun yang bersifat internasional. Di samping itu, keberadaan BANI di samping berfungsi menyelesaikan sengketa, ia juga dapat menerima permintaan yang diajukan oleh para pihak dalam suatu perjanjian untuk memberikan suatu pendapat (legal opinion) yang mengikat mengenai suatu persoalan.

\section{2)Badan Arbitrase Muamalat Indonesia (BAMUI)}

Perkembangan bisnis ummat Islam berdasar syari.ah semakin menunjukkan kemajuannya, maka kebutuhan akan lembaga yang dapat menyelesaikan persengketaan yang terjadi atau mungkin terjadi dengan perdamaian dan prosesnya secara cepat merupakan suatu kebutuhan yang sangat mendesak. Adapun tujuan dibentuk BAMUI adalah pertama: memberikan penyelesaian yang adil dan cepat dalam sengketa-sengketa muamalah perdata yang timbul dalambidang perdagangan, industri, keuangan, jasa dan lainlain, kedua : menerima permintaan yang diajukan oleh para pihak dalam suatu perjanjian tanpa adanya suatu sengketa untuk memberikan suatu pendapat yang mengikat mengenai suatu persoalan berkenaan dengan perjanjian tersebut.

\section{3)Badan Arbitrase Syariah Nasional (BASYARNAS)}

Badan Arbitrase Syariah Nasional (BASYARNAS) berkedudukan di Jakarta dengan cabang atau perwakilan di tempattempat lain yang dipandang perlu. Badan Arbitrase Syariah Nasional (BASYARNAS) sesuai dengan Pedoman Dasar yang di tetapkan oleh MUI : ialah lembaga hakam yang bebas, otonom dan independent, tidak boleh dicampuri oleh kekuasaan dan pihak-pihak manapun. Badan Arbitrase Syariah Nasional (BASYARNAS) adalah perangkat organisasi.

Sehingga pada prinsipnya penegakan hukum hanya dapat dilaksanakan dalam kekuasaan kehakiman (judicial Power) secara konstitusional yang disebut dengan nama badan yudikatif (Pasal 24 UUD 1945). Oleh karena itu yang berwenang memeriksa maupun yang mengadili sengketa hanya badan peradilan yang bernaung di bawah kekuasaan kehakiman yang berpuncak di Mahkamah Agung. Pasal 2 UU No. 14 Tahun 1970 secara tegas menyatakan bahwasanya yang berwenang dan berfungsi melakukan yakni peradilan h yang dibentuk melalui undang-undang. Di luar itu tidak dibenarkan sebab tidak memenuhi syarat formal maupun official serta bertentangan dengan prinsip under the 
authority of law (Pramudya, 2018). Namun berdasarkan Pasal 1851,1855,1858 KUHP, Penjelasan Pasal 3 UU No. 14 Tahun 1970 serta UU No. 30 Tahun 1999 mengenai Arbitrase dan Alternatif Penyelesaian Sengketa, hal ini terbuka kemungkinan para pihak menyelesaikan sengketa dengan menggunakan lembaga selain pengadilan (non litigasi), seperti arbitrase maupun perdamaian.

Untuk memperjelas dari masing-masing kelebihan ataupun kelemahan baik model dalam penyelesaian sengketa melalui jalur litigasi atau non litigasi sehingga perlu ditelaah satu persatu: (Hariyanto, 2014)

\section{Penyelesaian Sengketa Ekonomi Syariah Melalui Jalur Non Litigasi}

Di Indonesia, penyelesaian sengketa melalui jalur non litigasi telah diatur pada satu pasal, yakni Pasal 6 UU No. 30 Tahun 1999 tentang Arbitrase dan Alternatif Penyelesaian Sengketa.

a.Arbitrase

Dalam perspektif Islam arbitrase bisa disepadankan dengan istilah tahkim. Tahkim berasal dari kata hakkama, yakni secara etimologis memiliki arti menjadikan seseorang sebagai pencegah dalam sengketa. Pengertian tersebut erat kaitannya dalam pengertian menurut terminologisnya. Lembaga ini telah dikenal sejak zaman pra Islam.

Pada masa itu, walaupun belum memiliki sistem peradilan yang terorganisir, setiap ada perselisihan tentang hak milik, waris maupun hak- hak lainnya yang seringkali diselesaikan lewat bantuan juru damai ataupun wasit yang ditunjuk oleh masing-masing pihak yang berselisih. Gagasan pertama berdirinya lembaga arbitrase Islam di Indonesia, diawali dengan bertemunya para pakar, cendekiawan muslim, praktisi hukum, hingga para kyai maupun ulama agar dapat bertukar pikiran mengenai perlunya badan arbitrase Islam di Indonesia. Pertemuan ini gagasa oleh Dewan Pimpinan MUI pada tanggal 22 April 1992.

Setelah mengadakan beberapa kali rapat dan setelah diadakan beberapa kali penyempurnaan pada rancangan struktur organisasi dan prosedur beracara akhirnya pada tanggal 23 Oktober 1993 telah diresmikan Badan Arbitrase Muamalat Indonesia (BAMUI), yang saat ini sudah berganti nama menjadi Badan Arbitrase Syariah Nasional (BASYARNAS) yang diputuskan ketika Rakernas MUI tahun 2002. Perubahan bentuk dan pengurus BAMUI masukkan pada SK MUI No. Kep- 09/MUI/XII/2003 tanggal 24 Desember 2003 sebagai suatu lembaga arbiter yang menangani penyelesaian perselisihan sengketa di bidang ekonomi syariah.

b.Alternatif Penyelesaian Sengketa

Di dalam terminologi Islam sering dikenal dengan ash-shulhu, yang berarti memutus pertengkaran maupun perselisihan. Namun dalam pengertian syari'at ash-shulhu yaitu suatu jenis akad (perjanjian) dalam mengakhiri perlawanan (sengketa) antara 2 (dua) orang yang bersengketa. Alternatif penyelesaian sengketa hanya diatur oleh satu pasal, yakni Pasal 6 Undang- Undang No. 30 Tahun 1999 mengenai Arbitrase maupun Alternatif Penyelesaian sengketa memaparkan mengenai mekanisme penyelesaian sengketa.

Sementara sengketa dalam bidang perdata Islam bisa diselesaikan oleh para pihak melaui Alternative Penyelesaian Sengketa yang berdasarkan pada iktikad baik sehingga mengesampingkan penyelesaian secara litigasi. Namun apabila sengketa ini tidak bisa diselesaikan, maka atas kesepakatan tertulis para pihak, sengketa atau beda pendapat diselesaikan melalui bantuan seseorang individu atau lebih penasehat ahli hingga melalui seorang mediator.

Apabila para pihak tersebut pada waktu paling lambat 14 (empat belas) hari dengan bantuan seorang atau lebih penasehat ahli maupun melalui seorang mediator tidak berhasil juga mencapai kata sepakat, atau mediator tidak berhasil mempertemukan kedua belah pihak, maka para pihak dapat menghubungi lembaga Alternatif Penyelesaian Sengketa untuk menunjuk seorang mediator. Setelah penunjukan mediator oleh lembaga Alternatif 
Penyelesaian Sengketa, dalam waktu paling lama 7 (tujuh) hari usaha mediasi harus telah bisa dimulai.

\section{Penyelesaian Sengketa Ekonomi Syariah Melalui Jalur Litigasi}

Mengenai badan peradilan mana yang berwenang menyelesaikan perselisihan bila terjadi sengketa perbankan syariah memang sempat menjadi suatu perdebatan hingga berbagai kalangan. Apakah menjadi kewenangan

Pengadilan Umum atau Pengadilan Agama sebab atau memang belum ada undangundang yang secara tegas mengatur hal ini, sehingga masing-masing mencari landasan hukum yang tepat. Namun dengan diamandemennya Undang-Undang Nomor 7 Tahun 1989 mengenai Peradilan Agama oleh Undang-Undang Nomor 3 Tahun 2006 mengenai Perubahan atas Undang- Undang Nomor 7 Tahun 1989 mengenai Peradilan Agama, maka perdebatan mengenai siapa yang berwenang untuk menyelesaikan sengketa perbankan syariah sudah terjawab.

Undang-Undang Nomor 7 Tahun 1989 memberikan wewenang kekuasaan Peradilan Agama bertambah luas, yang semula sebagaimana diatur dalam Pasal 49 Undang-Undang Nomor 7 tahun 1989 hanya bertugas dan berwenang memeriksa, memutus, maupun menyelesaikan perkara ditingkat pertama diantara orang-orang yang beragama Islam di bidang :

a) perkawinan,

b) kewarisan, wasiat dan hibah yang dilakukan berdasarkan hukum Islam, dan

c) wakaf dan shadaqah. Sehingga adanya amandemen Undang-Undang tersebut, maka ruang lingkup tugas dan wewenang Peradilan Agama diperluas.

Berdasarkan Pasal 49 huruf (i) UU No. 3 Tahun 2006 Pengadilan Agama bertugas dan berwenang memeriksa, mengadili dan menyelesaikan perkara ditingkat pertama antara orang-orang yang beragama Islam dalam bidang ekonomi syariah yang meliputi: a) bank syariah, b) lembaga keuangan mikro syariah, c) asuransi syariah, d) reasuransi syariah, e) reksa dana syariah, f) obligasi syariah dan surat berharga berjangka menengah syariah, g) sekuritas syariah, h) pembiayaan syariah, i) pegadaian syariah, $\mathrm{j}$ ) dana pensiun lembaga keuangan syariah, dan k) bisnis syariah (Hardiati, 2021).

Dalam penjelasan Pasal tersebut dinyatakan diantaranya:

"Yang dimaksud dengan "antara orang-orang yang beragama Islam" ialah termasuk orang atau badan hukum yang dengan sendirinya menundukkan diri dengan sukarela kepada hukum Islam mengenai hal-hal yang menjadi kewenangan Pengadilan Agama sesuai ketentuan pasal ini."

Dari penjelasan Pasal 49 tersebut, maka seluruh nasabah lembaga keuangan dan lembaga pembiayaan syariah, atau bank konvensional yang membuka unit usaha syariah dengan sendirinya terikat dengan ketentuan ekonomi syariah, baik dalam pelaksanaan akad ataupun dalam menyelesaian perselisihan. Adapun sengketa di bidang ekonomi syariah yang menjadi kewenangan Pengadilan Agama (Suadi, 2017) adalah:

a. Sengketa di bidang ekonomi syariah antara lembaga keuangan dan lembaga pembiayaan syariah dengan nasabahnya;

b. Sengketa di bidang ekonomi syariah antara sesama lembaga keuangan dan lembaga pembiayaan syariah;

c. Sengketa di bidang ekonomi syariah antara orang-orang yang beragama Islam, yang mana akad perjanjiannya disebutkan dengan tegas bahwa kegiatan usaha yang dilakukan adalah berdasarkan prinsip-prinsip syariah.

Selain dalam hal kewenangan sebagaimana diuraikan di atas, Pasal 49 UU No. 3 Tahun 2006 juga mengatur tentang kompetensi absolute (kewenangan mutlak) Pengadilan Agama.

Oleh sebab itu, pihak-pihak yang melakukan perjanjian berpedoman pada prinsip 
syariah (ekonomi syariah) tidak bisa melaksankan pilihan hukum untuk diadili di Pengadilan yang lain. Sehingga sebagaimana tercantum pada Penjelasan Umum UU No. 3 Tahun 2006 alenia ke-2, pilihan hukum telah dinyatakan dihapus. Oleh karena itu, dalam draft-draft perjanjian yang dibuat oleh beberapa perbankan syariah berkaitan dengan perjanjian pembiayaan murabahah, akad mudharabah dan akad-akad yang lain yang masih mencantumkan klausul Penyelesaian sengketa di Pengadilan Negeri apabila BASYARNAS tidak dapat menyelesaikan sengketa sehingga seharusnya bila mengacu pada Penjelasan Umum UU No. 3 Tahun 2006 alenia ke-2, sehingga klausul ini diubah menjadi kewenangan Pengadilan Agama dalam menyelesaikan sengketa tersebut (Mujahidin, 2018).

Problematika kewenangan Pengadilan Agama dalam menyelesaikan sengketa di bidang ekonomi syariah adalah materi hukum berupa peraturan perundang-undang, yang mana saat ini selain undang-undang No. 3 Tahun 2006 tentang Peradilan Agama ada UU No. 19 Tahun 2008 tentang surat berharga syariah negara dan UU No. 21 Tahun 2008 mengenai perbankan syariah dengan penjabaran dalam berbagai peraturan telah cukup menjadi dasar melaksanaan kewenangan tersebut. Akan tetapi yang terjadi justru undangundang tersebut berbenturan dengan UU yang ada sebelumnya, Undang-Undang (UU) Arbitrase, UU Pasar Modal, UU Kepailitan, UU Perasuransian, UU Perdagangan, UU Pegadaian, UU Bank Indonesia, UU Perbankan, UU Hak Tanggungan, UU Jaminan Fidusia, UU Perseroan Terbatas, UU Dokumen Perusahaan, UU Jabatan Notaris, UU Persaingan Usaha (Anti Monopoli), UU Perlindungan Konsumen, UU Koperasi, UU Lembaga Penjaminan Simpanan dan menyangkut Otoritas Jasa Keuangan.

Terkait dengan penyelesaian sengketa perbankan syariah issue pokok benturannya antara lain dengan: Pertama, Undang-Undang Hak Tanggungan (UU No. 4 Tahun 1996). Undang-Undang ini mengakomodasi jaminan seperti tanah atau bangunan yang dalam kegiatan eksekusi jika debitur wanprestasi dapat dilaksankan lelang Hak Tanggungan secara di bawah tangan atau melalui Pengadilan Negeri. Dapatkah nantinya Pengadilan Agama juga mengakomodasi lelang Hak Tanggungan mengingat Pengadilan Negeri juga dapat melakukan hal yang sama sehingga dapat menimbulkan duplikasi. Kedua, UndangUndang Jaminan Fidusia mensyaratkan adanya pembuatan Akta Jaminan Fidusia dan pendaftaran di Kantor Pendaftaran Fidusia sehingga menimbulkan hak preferensi bagi kreditur. Pelaksanaan eksekusi Jaminan Fidusia juga hampir sama (mirip) dengan UndangUndang Hak Tanggungan, Apakah nantinya Pengadilan Agama juga dapat mengakomodasikan hal tersebut. Ketiga, Undang-Undang Kepailitan. Syarat kepailitan adalah debitur mempunyai 2 atau lebih kreditur, mempunyai hutang yang telah jatuh tempo dan dapat ditagih. Pengajuan kepailitan dilakukan ke Pengadilan Niaga.

Lantas, apakah Pengadilan Agama dapat berfungsi sebagai semacam Pengadilan Niaga Syariah untuk menerima suatu pengajuan kepailitan itu yang menjadi problematika Politik hukum Mahkamah Agung sebagai lembaga yang mempunyai kewenangan penyelesaian sengketa antar lembaga peradilan seharusnya mengambil langkah-langkah konkrit terkait aturan pelaksanaan dari ketentuan Undang-Undang, bahkan dalam perjalannya ada Surat Edaran Mahkamah yang keberadaannya saling tumpang tindih dan mekanisme penyelesaian sengketa ekonomi syariah dapat diselesaikan oleh tiga lembaga yaitu Pengadilan Agama, Pengadilan Negeri dan BASYARNAS jelas melemahkan eksistensi ketentuan UU No. 3 Tahun 2006 dan UU No.21 Tahun 2008 sehingga harus ada kejelasan tentang mekanisme penyelesaian sengketa syariah, yaitu harus mengembalikan pada Pengadilan Agama sebagai lembaga yang mempunyai kewenangan menyelesaikan sengketa ekonomi syariah Faktor ketiga Budaya hukum, sampai tahun ke-empat tahun disahkannya UU. No. 3 Tahun 2006 belum ada kemauan dari pihak-pihak terkait dalam optimalisasi pelaksanaan tugas dan kewenangan Peradilan Agama pasca lahirnya Undang- 
Undang Nomor 3 Tahun 2006 tentang Peradilan Agama dalam menyelesaikan sengketa ekonomi.

\section{KESIMPULAN}

Berdasarkan hasil penelitian Berdasaarkan pembahsan pada bab sebelumnya, maka penulis dapa menarik kesimpulan dari tulisan ini yakni: 1. Bahwa dalam menyelesaikan permasalah Sengketa Ekonomi Syariah berdasarkan tradisi Islam klasik Kl dapat ditempuh dengan cara di bawah ini:

a. Al Sulh (Perdamaian) Secara bahasa, berarti meredam pertikaian, sedangkan menurut istilah sulh berarti suatu jenis akad atau perjanjian untuk mengakhiri perselisihan/ pertengkaran antara dua pihak yang bersengketa secara damai.

b. Tahkim (artbitrase) berarti menjadikan seseorang sebagai pencegah suatu sengketa

c. Wilayat al Qadha (Kekuasaan Kehakiman) 2. Penyelesaian Sengketa Ekonomi Syariah Berdasarkan Tradisi Hukum Positif Indonesia dapat di tempuh dengan cara dibawah ini: a. Perdamaian dan Alternatif Penyelesaian Sengketa (ADR) b. Arbitrase (Tahkim)

\section{DAFTAR PUSTAKA}

Asrizal, Asrizal, and Armita Pipin. "Pilihan Penyelesaian Sengketa Ekonomi Syariah Bagi Masyarakat: Antara Ligitasi Dan Non-Ligitasi." Al-Amwal 7, no. 1 (2018): 44-55.

Hariyanto, Erie. "Penyelesaian Sengketa Ekonomi Syariah Di Indonesia." IQTISHADIA: Jurnal $\begin{array}{lllllll}\text { Ekonomi } \quad \& \quad \text { Perbankan } & \text { Syariah 1, no. } 1 & \text { (2014): } 42 .\end{array}$ https://doi.org/10.19105/iqtishadia.v1i1.365.

Ilyas, Musyfikah. "Tinjauan Hukum Islam Terhadap Musyawarah Dalam Penyelesaian Sengketa Ekonomi Syariah.” Jurnal Al-Qadau: Peradilan Dan Hukum Keluarga Islam 5, no. 2 (2018): 227-36.

Jamin, Mohammad. "Mekanisme Alternatif Penyelesaian Sengketa." Universitas Sebelas Maret (UNS), Surakarta, 1995.

Makarim, Abdussami. "Penyelesaian Sengketa Perbankan Syariah Lewat Mediasi Di Lembaga Litigasi Dan Non Litigasi (Studi Kasus: Pengadilan Agama Jakarta Selatan, Badan Arbitrase Syariah Nasional Jakarta, Dan Lembaga Penyelesaian Sengketa Perbankan Indonesia)." Fakultas Syariah dan Hukum UIN Syarif Hidayatullah Jakarta, 2019.

Mujahidin, Ahmad. Ruang Lingkup Dan Praktik Mediasi Sengketa Ekonomi Syari'ah. Deepublish, 2018.

Mukarromah, Safitri, and Wage Wage. "Penyelesaian Sengketa Ekonomi Syari'ah Di Lembaga Keuangan Syari'ah Kabupaten Banyumas.” Islamadina: Jurnal Pemikiran Islam, 2019, 6982.

Neni Hardiati, "Al-Hiwalah Dan Implementasinya Pada Perbankan Syariah Di Tinjau Dari Kaidah Fiqih," Syntax Idea 3, no. 1 (2021): 6.

Nurhayati, Nurhayati. "Penyelesaian Sengketa Dalam Hukum Ekonomi Islam.” Jurnal Hukum Ekonomi Syariah 3, no. 1 (2019): 01-11. https://doi.org/10.26618/j-hes.v3i1.2118.

Pramudya, Kelik. "Strategi Pengembangan Ekonomi Syariah Melalui Penguatan Fungsi Pengadilan Agama Dalam Penyelesaian Sengketa." Jurnal Rechts Vinding: Media Pembinaan Hukum Nasional 7, no. 1 (2018): 35-47.

Rahmi, Diana. "Subjek Hukum Dalam Perspektif Undang-Undang Tentang Peradilan Agama." 
Syariah: Jurnal Hukum Dan Pemikiran 14, no. 2 (2015).

Rinanda, Saskia Rizka. "Pengaruh Saham Syariah, Sukuk Dan Reksadana Syariah Terhadap Pertumbuhan Ekonomi Nasional Tahun 2013-2017".” Jakarta: Fakultas Ekonomi dan Bisnis UIN Syarif Hidayatullah Jakarta, 2018.

Suadi, Amran. Penyelesaian Sengketa Ekonomi Syariah Teori Dan Praktik. Vol. 1. Kencana, 2017.

Sugiyono. "Metode Penelitian Penelitian Kuantitatif, Kualitatif Dan R\&D." In Bandung: Alfabeta, 286-88, 2011.

Yulianti, Rahmani Timorita. "Sengketa Ekonomi Syari' Ah ( Antara Kompetensi Pengadilan Agama Dan Badan Arbitrase Syari ’ Ah ).” Al-Mawarid Edisi XVII (2007): 45-60. 